DOI: https://doi.org/10.32838/2523-4803/69-6-6

УДК 339.138

\title{
Рожко Н.Я.
}

кандидат економічних наук, доцент,

Тернопільський національний технічний університет імені І. Пулюя

\section{Шинкаренко Н.В.}

кандидат економічних наук, доцент,

Національний технічний університет «Дніпровська політехніка»

Таранський I.П.

кандидат економічних наук, доцент,

Національний університет «Львівська політехніка»

\author{
Rozhko Nataliya \\ Ternopil Ivan Puluj National Technical University \\ Shynkarenko Nataliya \\ National Technical University «Dnipro Polytechnic»
}

Taransky Igor

Lviv Polytechnic National University

\section{ОСТАННІ ТРЕНДИ РИНКУ ОВОЧІВ ТА ФРУКТІВ}

У статті розкрито ситуацію на ринку овочів та фруктів. Виявлено основні проблеми: відсутність системи збуту, логістики та брак коштів на запровадження та використання новітніх технологій, висока вартість фінансових ресурсів, тобто кредитів. Сформовано основні тендениії ринку овочів та фруктів, серед яких виділено необхідність інвестування, розширення обсягів виробничтва, зростання конкуренції; впровадження іноземних технологій; зростання якості продукції; розширення асортименту; розиирення сегменту екологічно чистої продукиії. Серед перспектив розвитку ринку овочів та фруктів виділено необхідність збільшення тепличного виробниитва; збільшення обсягу свіжих фруктів у мережах супермаркетів, таких як виноград, кісточкові, яблука та груші; розширення асортименту свіжої та здорової ӥжі.

Ключові слова: тренд, ринок, овочі, фрукти, попит, пропозиція, конкуренція.

Постановка проблеми. Вітчизняний ринок овочів і фруктів стає все більш привабливим для бізнесу, оскільки останнім часом зростають обсяги вітчизняного виробництва, спостерігається впровадження іноземних технологій; розширюється асортимент представлених на ринку свіжих фруктів, зростає попит на фрукти, зароджується ринок екологічно чистих продуктів. Відповідно, виникає необхідність дослідження останніх тенденцій ринку овочів та фруктів, виявлення проблем, які перешкоджають розвитку, визначення основних напрямів вирішення проблеми.

Аналіз останніх досліджень і публікацій. Проблеми та перспективи розвитку ринку овочів та фруктів досліджено вітчизняними та зарубіжними вченими, серед яких на особливу увагу заслуговують праці I.M. Демчака, В.О. Завалевської, О.О. Митченока, якими оприлюднено результати аналітичних досліджень щодо стану роздрібних цін на продуктових ринках. О.В. Шубравська, Н.А. Ринденко, П.О. Сухий досліджували європейський досвід та українські перспективи ринків овочів та фруктів.

Окрім того, у працях вітчизняних учених О.Ю. Бочко, С.В. Ковальчук, М.А. Козоріз, Є.В. Крикавського, Т.I. Лепейко, О.В. Мороза, М.А. Окландера, І.В. Петрик,
Й.М. Петровича, І.Л. Решетнікової, Н.Б. Савіної, Р.В. Садловського, С.В. Усенко, В.А. Фаловича, Н.I. Чухрай, Л.Я. Якимишин розкрито загальні аспекти функціонування ринку сільськогосподарської продукції. Проте, незважаючи на великий арсенал наукових доробок у цьому напрямі недостатньо вивченим $€$ ринок овочів та фруктів у світлі останніх економічних подій та ринкової ситуації.

Формулювання цілей статті. Мета статті - дослідити останні тренди ринку овочів та фруктів.

Виклад основного матеріалу. Овочі та фрукти характеризуються наявністю вітамінів, мінералів, клітковини та антиоксидантів, тому рекомендації щодо збалансованого харчування повинні включати їх споживання.

Сучасний ринок овочів і фруктів зростає дуже динамічно і стає все більш цивілізованим. Велику роль при цьому відіграють гуртові підприємства, які мають власну інфраструктуру для виробництва, переробки, транспортування, упаковки, зберігання і дистрибуції овочів та фруктів і міжнародні й міжрегіональні роздрібні торговельні мережі. Гарна упаковка та якісний продукт приваблюють сучасного споживача, що стимулює до зростання обсягів споживання. 
Підтверджуючи вищесказане, В.В. Писаренко стверджує, що за останні роки споживання овочів та фруктів зросло в усіх напрямах: у свіжому вигляді, для консервації, заморожування, сушіння тощо. Це призвело до значного підвищення цін на овочі та фрукти на внутрішньому ринку, оскільки збільшення площ під цими культурами професійними виробниками виявилося недостатнім, щоб повністю задовольнити попит, який різко підвищився. Споживачі все частіше віддають перевагу високоякісній плодоовочевій продукції в зручній упаковці, незважаючи на те що ціна на неї вища за альтернативні варіанти. Відповідні іноземні компанії почали активно інвестувати й у виробництво, й у переробку овочів та фруктів [7].

Пропри таку ситуацію, сьогодні сучасний українець не споживає належну фізіологічну норму овочів і фруктів. Внутрішній обсяг ринку ще не цілком заповнений через високий рівень цін.

На частку категорії «овочі та фрукти» впливають продажі з присадибних господарств. Так, улітку і на початку осені конкуренцію створюють місцеві присадибні господарства, частка овочів і фруктів в обороті не піднімається вище 7\%. Узимку вартість вітамінного асортименту зростає, відповідно, змінюється структура споживання і майже вдвічі збільшується частка в товарообороті [4].

Отже, хоча фрукти та овочі виробляються сезонно, проте ринок вимагає продукції протягом року. Протягом багатьох десятиліть ця проблема співставлення доступності товару зі споживчим попитом вирішувалася двома способами:

1. Продаж свіжої продукції під час збору врожаю та незабаром після цього.

2. Обробка залишків (вторсировини) для задоволення попиту протягом року.

У міру вдосконалення технології та збільшення доходів споживачів стало можливим забезпечення свіжою продукцією ринку овочів та фруктів цілорічно. Крім того, залишається великим попит на перероблені фрукти та овочі.

Цілорічний попит на свіжу продукцію змушують продавців шукати шляхи для виробництва плодоовочевої продукції, застосовуючи інноваційні технології чи збільшуючи обсяги імпорту. Проте споживачі та виробники на ринку овочів і фруктів стикаються з проблемами якісного упакування такої продукції з метою гарантії доступності якісної продукції 24/7.

За створених умов на допомогу гуртовим товаровиробникам можуть прийти фірми, які займаються упаковкою, з метою гарантування доставки свіжих фруктів та овочів, якіє доступними щотижня протягом року.

Будучи дрібним виробником свіжих фруктів і овочів, доцільно розглядати можливість продажу безпосередньо в межах роздрібної торгівлі. Хоча у деяких мережевих магазинах та незалежних роздрібних торговців $є$ місцеві програми для придбання свіжої продукції, такі магазини та програми не $є$ загальними. При цьому виробник $є$ одночасно і пакувальником, і гуртовим реалізатором.
На ринку овочів та фруктів можна виділити проблеми, які потребують негайного усунення. Зокрема, відсутні єдина система збуту, логістики та брак коштів на запровадження та використання новітніх технологій, висока вартість фінансових ресурсів, тобто кредитів (рис. 1).

Для українських гравців ринку овочів та фруктів можна сформувати такі основні тенденції:

1. Необхідність інвестування шляхом збільшення кількості комерційних проєктів.

2. Зростання обсягів виробництва деяких фруктів та овочів.

3. Зростання конкуренції на зовнішньому та внутрішньому ринках.

4. Відсутність єдиних стандартів якості, адаптованих до вимог $\mathrm{CC.}$

5. Впровадження іноземних технологій (від вирощування, логістики до сортування, калібрування й упакування).

6. Зростання якості вітчизняної продукції.

7. Розширення асортименту представлених на ринку свіжих фруктів, у тому числі екзотичних.

8. Постійне зростання попиту на фрукти.

9. Підвищення споживчої культури на досліджуваному ринку, у тому числі завдяки прагненню все більшого числа людей вести здоровий спосіб життя.

10. Зародження ринку екологічно чистих продуктів, для розвитку якого в Україні існують реальні можливості.

11. Ринок стає більш цивілізованим: з'являються великі оптові компанії, які мають власну інфраструктуру для заготівлі, транспортування, упаковки, зберігання та дистрибуції овочів і фруктів [1].

«Водночас ефект масштабу має велике значення. Тому на овочевому ринку майбутнє - за великими спеціалізованими підприємствами, які можуть вирощувати овочі із застосуванням інноваційних технологій, із більш низькою собівартістю, а отже, реалізовувати свою продукцію за більш низькими цінами та сприяти збільшенню споживання овочів населенням», - уважає Л.М. Галат [2]. В Україні вже $\epsilon$ чимало великих підприємств та фермерських господарств, які працюють із використанням сучасних світових технологій, включаючи зберігання, доробку, збут, сертифікацію, а інколи переробку і брендування.

Серед основних перспектив розвитку ринку овочів та фруктів доцільно відзначити такі.

По-перше, збільшення тепличного виробництва, що дає можливість отримати більш високу ціну за вирощену продукцію та вийти на експортні ринки у вільні вікна.

По-друге, збільшення обсягу свіжих фруктів у мережах супермаркетів, таких як виноград, кісточкові, яблука та груші. Супермаркети рідко купляють місцеву продукцію, оскільки імпортована має високу якість навіть протягом основного сезону українських овочів та фруктів. Ця продукція постачається охолодженою, запакованою, з відповідним строком реалізації продукції. 


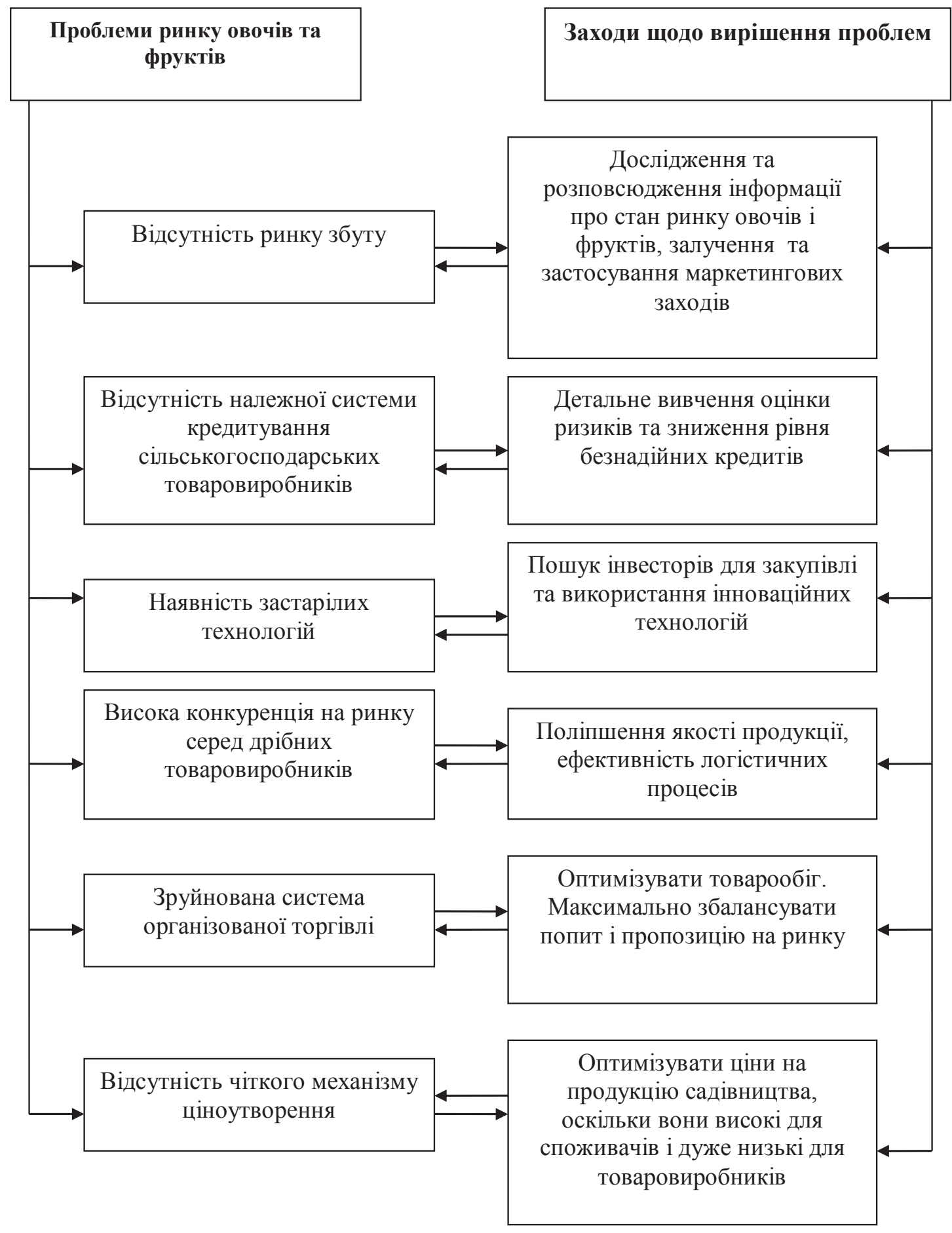

Рис. 1. Основні проблеми та шляхи їх вирішення на ринку овочів та фруктів в Україні

Джерело: систематизовано авторами

По-трете, зміна споживацьких трендів - свіжа та здорова їжа, вегетаріанство, що є нішевим сегментом та передбачає появу нових продуктів на ринку (снеків).

У результаті проведеного дослідження ринку овочів і фруктів пропонуємо:

1) дрібним виробникам: визначити географію реалізації овочів і фруктів; визначити сегмент потенційних клієнтів та спрямувати зусилля на дану категорію; поліпшити рівень обслуговування; застосувати комплекс маркетингових комунікацій;

2) великим виробникам: збільшити обсяги експорту овочів і фруктів; збільшити обсяги переробки та консервування, поліпшити умови зберігання плодоовочевої продукції.

«Перспективами розвитку плодоовочівництва $€$ зміна споживацьких трендів - свіжа та здорова їжа, вегетаріанство, що є нішевим сегментом та вимагає 
появи нових продуктів на ринку (снеки); а також маркетинг та просування продукції - створення брендованої продукції, контрактне вирощування та зростання експорту (валютна виручка, повернення ПДВ, стабільність, більш висока ціна)», - доводить В.А. Ковтун [5].

Висновки. Отже, у результаті проведених досліджень ринку овочів та фруктів нами виділено основні тренди сучасного ринку:

- необхідність інвестування, особливо у закупівлю нових технологій для поліпшення якості зберігання та упакування; потужностей для заморожування плодоовочевої продукції;
- збільшення обсягів виробництва, використовуючи нові види сортів та органічних добрив;

- розширення асортименту за рахунок використання якісного насіння і посадкового матеріалу;

• збільшення частки екопродукції з використанням спеціальної методики виробництва, що дає змогу зберегти максимальну кількість вітамінів у продукції.

Підтримка вказаних трендів та їх розвиток повинні забезпечуватися державою для захисту сучасного споживача. Отже, перспективо подальших досліджень у цьому напрямі є формування законодавчого захисту сучасного споживача та внесення пропозицій щодо побудови здорової конкуренції вітчизняної продукції на ринках $Є С$.

\section{Список літератури:}

1. Близкий Р.С. Формирование рынка овощей и фруктов в Украине. Науковий вісник Полтавського університету економіки і торгівлі. 2011. № 1(45). С. 28-31.

2. Галат Л.М. Особливості ринку свіжих овочів в Україні. Агросвіт. 2019. № 11. С. 35-44.

3. Аналітичні дослідження роздрібних цін на продуктових ринках / I.М. Демчак та ін. Київ : Украгропромпродуктивність, 2013.90 с.

4. Діденко М. Онлайн-СМИ о бизнесе розничной и Интернет-торговли. URL : http://retailers.ua/z7 (дата звернення: 20.11.2019).

5. Ковтун В.А. Проблеми та перспективи розвитку малого та середнього бізнесу Півдня України під час виробництва плодоовочевої продукції. URL : https://chmnu.edu.ua/wp-content/uploads/2019/07/Kovtun-V.-A.pdf (дата звернення: 18.11.2019).

6. Оптовая торговля : инфраструктура и тенденции развития : монография/ под ред. Е.М. Азарян. Донецк : ДонГУСТ, 2005. 292 c.

7. Писаренко В.В. Маркетинг овощной продукции (методические и практические аспекты): состояние производства овощей в Украине. URL : https://agromage.com/stat_id.php?id=321 (дата звернення: 10.11.2019).

8. Сухий П.О., Заячук М.Д. Сучасний стан та перспективи розвитку овочівництва в Україні. Ученые записки Таврического национального университета им. В.И. Вернадского. 2012. № 3. С. 38-48.

9. Шубравська О.В., Ринденко Н.А. Оптові ринки сільськогосподарської продукції: європейський досвід та українські перспективи. Економіка України. 2012. № 8. С. 77-85.

\section{References:}

1. Blyzkyi R.S. (2011) Formyrovanye runka ovoshchei y fruktov v Ukrayne. [Formation of the market of vegetables and fruits in Ukraine]. Naukovyi visnyk Poltavskoho universytetu ekonomiky i torhivli [Scientific Bulletin of Poltava University of Economics and Trade.], vol. 1(45), pp. 28-31

2. Halat L.M. (2019) Osoblyvosti rynku svizhykh ovochiv v Ukraini [Features of the market of fresh vegetables in Ukraine]. Ahrosvit [Agro-world], no. 11, pp. 35-44.

3. Demchak I.M., Zavalevska V.O., Mytchenok O.O. ta in. (2013) Analitychni doslidzhennia rozdribnykh tsin na produktovykh rynkakh [Analytical studies of retail prices in the product markets]. K.: NDI «Ukrahropromproduktyvnist», 90 s. (accessed on: 20.11.2019).

4. Didenko M. Onlain-SMY o byznese roznychnoi y ynternet torhovly [Online-media about the business of retail and online trade]. Available at: http://retailers.ua/z7 (accessed 20.11.2019).

5. Kovtun V.A. Problemy ta perspektyvy rozvytku maloho ta serednoho biznesu pivdnia Ukrainy pid chas vyrobnytstva plodoovochevoi produktsii [Problems and prospects of development of small and medium business in the south of Ukraine during production of fruit and vegetable products]. Available at: https://chmnu.edu.ua/wp-content/uploads/2019/07/KovtunV.-A. Pdf (accessed 18.11.2019).

6. Azarian E.M. (2005) Optovaia torhovlia : infrastruktura y tendentsyy razvytyia: monohrafyia [Wholesale trade: infrastructure and development trends]. Pod red. E.M. Azarian. Donetsk: Don. HUIeT. 292 s.

7. Pysarenko V.V. Marketynh ovoshchnoi produktsyy (metodycheskye y praktycheskye aspektы) : sostoianye proyzvodstva ovoshchei v Ukrayne. [Marketing of vegetable products (methodical and practical aspects): the state of vegetable production in Ukraine]. Available at: https://agromage.com/stat_id.php?id=321(accessed 10.11.2019).

8. Sukhyi P.O., Zaiachuk M.D. (2012) Suchasnyi stan ta perspektyvy rozvytku ovochivnytstva v Ukraini [Current status and prospects of vegetable growing in Ukraine.]. Uchenye zapysky Tavrych. nats. Un-ta ym. V.Y. Vernadskoho. [Scientific notes Tavrich. nat. Their university Vernadsky], no. 3, pp. 38-48.

9. Shubravska O.V., Ryndenko N.A. (2012) Optovi rynky silskohospodarskoi produktsii : yevropeiskyi dosvid ta ukrainski perspektyvy [Wholesale markets of agricultural products: European experience and Ukrainian prospects]. Ekonomika Ukrainy [Ukraine economy], no. 8, pp.77-85. 


\section{ПОСЛЕДНИЕ ТРЕНДЫ РЫНКА ОВОЩЕЙ И ФРУКТОВ}

В статье раскрыта ситуация на рынке овощей и фруктов. Выявлены основные проблемы: отсутствие системы сбыта, логистики, недостаток средств на внедрение и использование новейших технологий, высокая стоимость финансовых ресурсов, то есть кредитов. Сформированы основные тенденции рынка овощей и фруктов, среди которых выделень необходимость инвестирования, расширения объемов производства, рост конкурениии; внедрение иностранных технологий; рост качества продукции; расширение ассортимента; расширение сегмента экологически чистой продукиии. Среди перспектив развития рынка овощей и фруктов выделена необходимость увеличения тепличного производства; увеличения объема свежих фруктов в сетях супермаркетов, таких как виноград, косточковые, яблоки и груши, расширение ассортимента свежей и здоровой пищи.

Ключевые слова: тренд, рынок, овощи, фрукты, спрос, предложение, конкуренция.

\section{RECENT TRENDS AT THE MARKET OF FRUIT AND VEGETABLES}

Timeliness of examination of the market of fruit and vegetables is caused by its inelastic demand. It is forced by the necessity to buy products regardless of their prices. The article examines the situation at fruit and vegetable market. The work highlights the main problems, particularly lack of efficient system of sales, adequately developed logistics, and lack of funds for introduction and employment of innovative technologies; high costs of financial resources, i.e. credits. The author of the research outlines the principal trends at the market of fruit and vegetables, including the necessity of investing, extension of the volume of production, strengthening of competition; introduction of foreign technologies; increase of products' quality; extension of the range of products generally and in the segment of ecologically clean products particular; increase of the share of fresh segment, growth of branding. A particular attention is paid to improvement of performance of wholesaling and retailing commodity producers. The author of the work proposes to make clear determination of the geography of sales of fruit and vegetables by small producers; to argue the segment of potential clients and focus their efforts on the mentioned category; to improve the level of servicing; to apply a complex of marketing communications. Wholesalers are proposed to focus their efforts on increase of the volume of export of fruit and vegetables, processing and conservation, on improvement of the conditions of fruit and vegetables storage. It is determined that improvement of the market of fruit and vegetables is caused by the factors, like growth of the middle class population, increase of available income, rapid urbanization, transformation of the way of living of consumers and their focus on healthy living. However, growth of that market is restrained by the following problems, particularly fluctuation of prices, unfavorable weather conditions, and problems of quality. To develop the market of fruit and vegetables, it is proposed to concern improvement of quality and safety of products, to optimize the pricing policy, to focus efforts on growth of productive capacities and amount of sales, to increase the volume of glasshouse industry and fresh products in supermarket chains, as well as to extend the range of fresh and healthy food.

Key words: trend, market, vegetables, fruit, demand, supply, competition. 